\title{
QUALITY CHARACTERISTICS OF CORN TORTILLA PREPARED WITH DIFFERENT LEVELS OF RICE BRAN PROTEIN CONCENTRATE
}

\author{
A. M. Ezzeldeen(1), E. H. Mansour(2), Mona M. Ali(1), Amal A. Hassan(2) and \\ A. A. El-Bedawey ${ }^{(2)}$ \\ (1) Crops Technology Department, Food Technology Research Institute, Agricultural \\ Research Center, Giza, Egypt. \\ (2) Department of Food Science and Technology, Faculty of Agriculture, Menoufia \\ University, 3251 Shibin El-Kom, Egypt
}

Received: Jul. 28,2019

Accepted: Sep. 4, 2019

\begin{abstract}
This study was conducted to evaluate the possibility of partial replacement of yellow corn flour with rice bran protein concentrate (RBPC) to prepare highly nutritive and acceptable tortilla. The crude protein and total ash contents of tortilla were increased $(p \leq 0.05)$ by increasing the level of RBPC in a tortilla. However, total carbohydrates, crude fat and crude fiber had an opposite trend. The caloric values of tortilla were not affected $(p>0.05)$ by RBPC. Alkaline water retention capacity of the tortilla was increased $(p \leq 0.05)$ by increasing RBPC levels in the tortilla. However, it was decreased $(p \leq 0.05)$ by increasing the storage period from 24 to 72 hours. Tortilla prepared with RBPC had darker color than control tortilla. Tortilla prepared with $7.5 \%$ RBPC had higher lysine (27.31\%) and tryptophan (33.33\%) than control tortilla. In-vitro protein digestibility of tortilla was increased $(p \leq 0.05)$ by increasing the RBPC up to 7.5\%. Control tortilla had sensory rating scores ranged from 4.35 (neither like nor dislike) to 6.75 (like very much) for all sensory properties. However, tortilla prepared with $7.5 \%$ RBPC had rating scores ranged from 5.35 (like moderately) to 6.95 (like very much) for all sensory properties. The results showed that partial replacement of corn flour with $7.5 \%$ of RBPC resulted in an improvement in the nutritive value and overall acceptability of the tortilla.
\end{abstract}

Key words: Corn flour, rice bran protein concentrate, tortilla, lysine, overall acceptability

\section{INTRODUCCTION}

Rice bran protein concentrate is a good source of lysine and methionine and can be used as an effective tool to supplement the lysine and methionine deficient foods such as wheat, maize and sorghum (Sohail et al., 2017). Rice bran is a rich source of B-vitamins and minerals such as potassium, calcium, magnesium and iron (Michael et al., 2013). Rice bran protein is a good source of well-balanced amino acid and bioactive phytochemicals such as Y-oryzanol, tocopherols, tocotrienols, phytosterols and phenolic compounds that have antioxidant activities, as well as other reported health-beneficial properties (Rohrer and Siebenmorgen, 2004 and Sohail et al., 2017). Flours with $11.0-11.5 \%$ protein content yielded more shelf-stable tortillas (Waniska et al., 2004). Addition of commercial wheat protein fractions to the tortilla formulation improves tortilla shelfstability (Pascut et al., 2004 and Alviola et al., 2008). Supplementation of corn flour with different levels of chia flour improved the nutritive value of tortilla (Rendon-Villalobos et al., 2012). Montemayor-Mora et al. (2018) reported that enrichment wheat flour with 5 or $10 \%$ 
of soybean residue improved lysine and dietary fiber contents of a wheat flour tortilla.

Due to the nutritional deficiency in corn tortilla the current study was designed to incorporate different levels of RBPC in preparation of corn tortilla. The proximate composition, physical properties, color, alkaline water retention capacity, in-vitro protein digestibility, textural profile and sensory properties of tortilla were evaluated.

\section{MATERIALS AND METHODS Materials}

Yellow corn flour was obtained from Zamzam for Food Industries Co., EIMokatm, Cairo Governorate, Egypt. Rice bran (Oryza sativa L.) was obtained from the Rice Research and Training Center, Sakha, Kafr El-Sheikh Governorate, Egypt.

\section{Methods}

\section{Preparation of rice bran protein concentrate}

Fresh rice bran was defatted twice using hexane according to Wang et al. (1999). The rice bran and solvent ratio was $1: 3(\mathrm{w} / \mathrm{v})$. The mixture was shacked at room temperature $\left(\sim 25^{\circ} \mathrm{C}\right)$ for $30 \mathrm{~min}$. The defatted rice bran was dried at room temperature $\left(\sim 25^{\circ} \mathrm{C}\right)$ overnight, then ground to sieve through a 60 mesh screen.

The defatted rice bran was added to distilled water at 1:4 w/v ratios. The $\mathrm{pH}$ of the mixture was adjusted to $\mathrm{pH} 10.0$ (sodium hydroxide $0.1 \mathrm{~N}$ ). The mixture was shacked at room temperature $\left(\sim 25^{\circ} \mathrm{C}\right)$ for $30 \mathrm{~min}$ then centrifuged (Beckman J2-MC, USA centrifuge) at $\mathbf{3 0 0 0}$ rpm for $30 \mathrm{~min}$. The $\mathrm{pH}$ of the supernatant was adjusted to $\mathrm{pH} 4.0(\mathrm{HCl}$ $0.1 \mathrm{~N})$ then centrifuged at $\mathbf{3 0 0 0} \mathrm{rpm}$ for $\mathbf{3 0}$ min. The $\mathrm{pH}$ of the precipitate was adjusted to $\mathrm{pH} \quad 7.0(\mathrm{HCl} \quad 0.5 \mathrm{~N})$ then washed three times using distilled water and centrifuged at $\mathbf{3 0 0 0} \mathrm{rpm}$ for $\mathbf{3 0} \mathrm{min}$ after each washing time. The precipitate was frozen at $-10^{\circ} \mathrm{C}$ overnight then dried using freeze-dryer (Freeze dryer, FlexiDry $\mu$ P FTS ${ }^{\mathrm{TM}}$ system). The RBPC was packed in polyethylene bags and kept at $5^{\circ} \mathrm{C}$ until use.

\section{Preparation of tortilla}

Corn tortilla was prepared as described by Rendón-Villalobos et al. (2009). One hundred gram of yellow corn flour and $2 \mathrm{ml}$ of corn oil were mixed for 2 min on the hot plate. Boiled water (120 $\mathrm{ml}$ ) was added to corn flour-corn oil mixture with mixing until forming the dough. The dough was cut into pieces each piece weighed $35 \mathrm{~g}$. Each piece is formed into a round thin layer with $1 \mathrm{~mm}$ thick. The formed dough was baked on a hot plate at $250^{\circ} \mathrm{C}$ for $30 \mathrm{~s}$ on the first side and $40 \mathrm{~s}$ for the second side. The baked tortilla was cooled at room temperature $\left(\sim 25^{\circ} \mathrm{C}\right)$ for $3 \mathrm{~min}$ then frozen at $-18^{\circ} \mathrm{C}$ until use.

To prepare yellow corn flour-rice bran protein concentrate composite flour tortillas, the yellow corn flour in the control tortilla formula was replaced with different levels of rice bran protein concentrate $(2.5,5,7.5$ and $10 \%)$. The same procedure described above for the control tortilla was followed.

\section{Analytical methods Proximate composition}

Moisture, crude protein, crude fat, total ash, and crude fiber contents were determined in rice bran protein concentrate, corn flour and tortilla according to the method described by AOAC (2010). The total carbohydrate was calculated by difference.

\section{Amino acid profiles}

Amino acids profiles of tortilla were carried out according to the AOAC (2010) using an Amino Acid Analyzer (Biochrom 30). 
Tryptophan was determined according to the methods of Hernandes and Bates (1969) as follows:

Lysine $=$ tryptophan $\times(3.04+0.5)$

In-vitro protein digestibility

In-vitro protein digestibility was determined according to method described by Aksson and Stammann (1983).

\section{Alkaline water retention capacity \\ Alkaline water retention capacity of} tortilla was determined according to the method of Kitterman and Rubentholar (1971). Alkaline water retention capacity was determined at zero, 24, 48 and $72 \mathrm{~h}$ of storage at room temperature $\left(\sim 25^{\circ} \mathrm{C}\right)$.

\section{Color}

Color of tortilla was measured using reflectance colorimeter (model CR-400, Konica Minolta, Japan). The color profile system of lightness ( $L^{*}, 100$ lightness to zero darkness), redness $\left(a^{*},(-)\right.$ green to $(+)$ red) and yellowness $\left(b^{*},(-)\right.$ blue to $(+)$ yellow) was used.

The total color difference from the control $(\Delta E)$ was calculated as follows:

$\Delta E=\sqrt{ }\left(L_{o}{ }^{*}-L^{*}\right)^{2}+\left(a_{\circ}{ }^{*}-a^{*}\right)^{2}+\left(b_{0}{ }^{*}-b^{*}\right)^{2}$

$0=$ color reading for control

\section{Sensory properties}

Ten trained panelists were used for evaluating the sensory properties of tortilla. The coded samples were served to each panelist. The color, odor, taste, texture and overall acceptability were measured for the tortilla. Seven points hedonic scale was used for each trait where $7=$ like extremely, $6=$ like very much, 5 = like moderately, $4=$ neither like nor dislike, 3 = dislike moderately, 2 = dislike very much and $1=$ dislike extremely.

\section{Statistical analysis}

Data were presented as the mean \pm standard deviations. Data of sensory properties were the mean of ten replicates. However, other data were the mean of three replicates except for amino acids. Alkaline water retention capacity was analyzed by two-way analysis of variance using Costat version 6.311 (Copyright 1998-2005, CoHort software). The other data were analyzed by one-way analysis of variance. The LSD test was used for comparing among means. The difference among samples was considered significant at the $5 \%$ level.

\section{RESULTS AND DISCUSSION}

\section{Proximate composition of tortilla}

The proximate composition of rice bran protein concentrate, corn flour and tortilla prepared by replacing corn flour with different levels of rice bran protein concentrate was presented in Table (1). The rice bran protein concentrate had higher $(p \leq 0.05)$ crude protein and total ash and lower ( $p \leq 0.05)$ moisture, crude fat, crude fiber, total carbohydrates contents and caloric value than corn flour. Chandi and Sogi (2007) reported that the crude protein content of rice bran protein concentrate was in the range of $47.69-73.14 \%$. The moisture and crude protein contents of corn flour were comparable with the values reported by Argüello-García et al. (2017).

The crude protein and total ash contents of tortilla were significantly ( $p \leq$ 0.05 ) increased by increasing the level of rice bran protein concentrate in the tortilla. However, total carbohydrates, crude fat and crude fiber had an opposite trend. The increase in crude protein and total ash as well as the decrease in total carbohydrates, crude fat and crude fiber contents might be attributed to the increase in rice bran protein concentrate in tortilla which had higher crude protein and total ash contents and lower total carbohydrates, crude fat and crude fiber contents than corn flour. The similar increase in ash and decrease in fiber were reported by Argüello-García et al. 
A. M. Ezzeldeen, et al.,

(2017) for the tortillas fortified with nontoxic Jatropha curcas flour. Also, the similar increase in crude protein and decrease in the nitrogen-free extract were reported by Acevedo-Pacheco and Serna-Saldı́var (2016) for maize tortilla fortified with $6 \%$ defatted soybean.

The caloric values of tortilla were not affected $(p>0.05)$ by replacing corn flour with different levels of rice bran protein concentrate in a tortilla. The increase in protein is compensated by the decreasing in total carbohydrates, where both protein and carbohydrates are given $4 \mathrm{Kcal}$ when calculating the total caloric values. On the other hand, moisture contents were increased ( $p \leq 0.05$ ) by replacing corn flour with rice bran protein concentrate in a tortilla. The increase in moisture content might be attributed to the increase in protein content, which retained more water (Salinas et al., 2011). The moisture contents were within the range $35-50 \%$ reported by Agama et al. (2004) for tortillas and lower than the values (44.07-47.83\%) reported by Argüello-García et al. (2017) for the tortillas fortified with nontoxic Jatropha curcas flour.

Table (1): Proximate composition and caloric values of rice bran protein concentrate, corn flour and tortilla prepared by replacing corn flour with different levels of rice bran protein concentrate (on the dry weight basis)

\begin{tabular}{|c|c|c|c|c|c|c|c|}
\hline & Moisture & $\begin{array}{c}\text { Crude } \\
\text { protein }\end{array}$ & $\begin{array}{l}\text { Total } \\
\text { ash }\end{array}$ & $\begin{array}{l}\text { Crude } \\
\text { fat }\end{array}$ & $\begin{array}{l}\text { Crude } \\
\text { fiber }\end{array}$ & $\begin{array}{c}\text { Total } \\
\text { carbo- } \\
\text { hydrates }\end{array}$ & $\begin{array}{l}\text { Caloric } \\
\text { values }\end{array}$ \\
\hline & & & & & & & Kcal $/ 100 \mathrm{~g}$ \\
\hline \multirow[t]{2}{*}{${ }^{1} \mathrm{RBPC}$} & $3.21^{b}$ & $72.38^{a}$ & $1.96^{\mathrm{a}}$ & $1.30^{b}$ & $0.15^{b}$ & $24.21^{b}$ & $398.10^{b}$ \\
\hline & \pm 0.25 & \pm 0.26 & \pm 0.04 & \pm 0.02 & \pm 0.04 & \pm 0.23 & \pm 0.19 \\
\hline \multirow[t]{2}{*}{ Corn flour } & $8.69^{a}$ & $9.17^{b}$ & $1.43^{b}$ & $2.85^{\mathrm{a}}$ & $1.17^{\mathrm{a}}$ & $85.38^{a}$ & $403.85^{a}$ \\
\hline & \pm 0.18 & \pm 0.22 & \pm 0.07 & \pm 0.08 & \pm 0.06 & \pm 0.21 & \pm 0.65 \\
\hline LSD & 0.23 & 0.35 & 0.10 & 0.13 & 0.21 & 0.42 & 1.52 \\
\hline \multicolumn{8}{|c|}{ Tortilla with different levels of RBPC (\%) } \\
\hline \multirow[t]{2}{*}{0} & $36.22^{e}$ & $8.08^{e}$ & $1.99^{e}$ & $2.87^{a}$ & $0.99^{a}$ & $86.07^{a}$ & $402.43^{a}$ \\
\hline & \pm 0.03 & \pm 0.01 & \pm 0.05 & \pm 0.18 & \pm 0.01 & \pm 0.21 & \pm 2.04 \\
\hline \multirow[t]{2}{*}{2.5} & $37.13^{d}$ & $9.96^{\mathrm{d}}$ & $2.21^{d}$ & $2.77^{b}$ & $0.94^{b}$ & $84.12^{b}$ & $401.02^{a}$ \\
\hline & \pm 0.06 & \pm 0.05 & \pm 0.01 & \pm 0.36 & \pm 0.06 & \pm 0.16 & \pm 0.53 \\
\hline \multirow[t]{2}{*}{5} & $37.97^{c}$ & $11.63^{c}$ & $2.26^{c}$ & $2.71^{c}$ & $0.90^{c}$ & $82.50^{c}$ & $400.92^{a}$ \\
\hline & \pm 0.03 & \pm 0.04 & \pm 0.01 & \pm 0.06 & \pm 0.05 & \pm 0.01 & \pm 0.66 \\
\hline \multirow[t]{2}{*}{7.5} & $38.34^{b}$ & $13.60^{b}$ & $2.30^{b}$ & $2.60^{\mathrm{d}}$ & $0.85^{d}$ & $80.75^{d}$ & $400.66^{a}$ \\
\hline & \pm 0.06 & \pm 0.01 & \pm 0.04 & \pm 0.02 & \pm 0.02 & \pm 0.41 & \pm 0.38 \\
\hline \multirow[t]{2}{*}{10} & $39.08^{a}$ & $15.61^{a}$ & $2.36^{a}$ & $2.54^{\mathrm{e}}$ & $0.80^{\mathrm{e}}$ & $78.69^{e}$ & $399.66^{a}$ \\
\hline & \pm 0.05 & \pm 0.04 & \pm 0.01 & \pm 0.01 & \pm 0.06 & \pm 0.01 & \pm 0.46 \\
\hline
\end{tabular}

Means in the same column with different letters are significantly different $(p \leq 0.05)$ 
In-vitro protein digestibility of tortilla

In-vitro protein digestibility of tortilla prepared by replacing corn flour with different levels of rice bran protein concentrate was presented in Table (2). In-vitro protein digestibility of control tortilla was $41.79 \%$. This value was much lower than the value $\mathbf{( 7 2 . 5 \% )}$ reported by Acevedo-Pacheco and Serna-Saldı'var (2016) for maize tortilla fortified with $6 \%$ defatted soybean and the value $(84.9 \%)$ reported by Lecuona-Villanueva et al. (2012) for tortilla fortified with protein concentrate from Phaseolus lunatus. This difference might be due to the corn interspecies variation, growing conditions, storage conditions and the methods of tortilla.

Control tortilla had lower ( $p \leq 0.05)$ invitro protein digestibility than tortilla prepared with rice bran protein concentrate. In-vitro protein digestibility of tortilla was significantly ( $p \leq 0.05$ ) increased by increasing the level of rice bran protein concentrate up to $7.5 \%$. Similar improvement in in-vitro digestibility was reported by LecuonaVillanueva et al. (2012) for tortilla fortified with protein concentrate from Phaseolus lunatus. These results have differed from those reported by Serna-Saldivar et al. (1988) for maize-decorticated sorghum tortillas fortified with $8 \%$ soybean. A nonsignificant $(p>0.05)$ difference in in-vitro protein digestibility was observed between tortilla prepared with 7.5 and $10 \%$ rice bran protein concentrate.

\section{Alkaline water retention capacity of tortilla}

Alkaline water retention capacity of tortilla prepared by replacing corn flour with different levels of rice bran protein concentrate was presented in Table (3). Alkaline water retention capacity of the tortilla was significantly $(p \leq 0.05)$ increased by increasing rice bran protein concentrate levels. This might be attributed to the retention of water which absorbed by rice bran protein concentrate during the processing of tortilla. However, alkaline water retention capacity of the tortilla was significantly ( $p$ $\leq 0.05$ ) decreased by increasing the storage period from 24 to 72 hours. Kim and D'Appolonia (1977) reported that high protein content often resulted in a lower staling rate. Protein influences the crystallization process of starch directly and the distribution of water.

Table (2): In-vitro protein digestibility of tortilla prepared by replacing corn flour with different levels of rice bran protein concentrate

\begin{tabular}{lc}
\hline $\begin{array}{l}\text { Replacer levels } \\
(\%)\end{array}$ & $\begin{array}{c}\text { In-vitro protein digestibility } \\
(\%)\end{array}$ \\
\hline 0 & $41.79^{\mathrm{d}} \pm 0.21$ \\
2.5 & $56.76^{\mathrm{c}} \pm 0.24$ \\
5 & $57.87^{\mathrm{b}} \pm 0.18$ \\
7.5 & $59.06^{\mathrm{a}} \pm 0.56$ \\
10 & $58.95^{\mathrm{a}} \pm 0.43$ \\
LSD & 0.63 \\
\hline Means in the same column with different letters are significantly different $(\mathrm{p} \leq 0.05)$
\end{tabular}


A. M. Ezzeldeen, et al.,

Table (3): Alkaline water retention capacity of tortilla prepared by replacing yellow corn flour with different levels of rice bran protein concentrate

\begin{tabular}{|c|c|c|c|c|c|}
\hline \multirow{2}{*}{$\begin{array}{l}\text { Replacer } \\
\text { levels } \\
\text { (\%) }\end{array}$} & \multicolumn{4}{|c|}{ Storage period (Hours) } & \multirow[t]{2}{*}{${ }^{1}$ Means } \\
\hline & $\begin{array}{llll}0 & & & \\
\end{array}$ & 24 & 48 & 72 & \\
\hline 0 & 400.15 & 383.18 & 354.19 & 310.18 & $361.93^{e} \pm 0.40$ \\
\hline 2.5 & 413.58 & 399.47 & 374.44 & 341.44 & $382.23^{d} \pm 0.54$ \\
\hline 5 & 423.83 & 410.72 & 388.54 & 366.13 & $397.26^{\mathrm{c}} \pm 0.57$ \\
\hline 7.5 & 421.65 & 411.64 & 399.51 & 387.43 & $405.06^{b} \pm 0.62$ \\
\hline 10 & 430.22 & 416.34 & 404.06 & 393.54 & $411.04^{\mathrm{a}} \pm 0.55$ \\
\hline${ }^{2}$ Means & $417.89^{a} \pm 0.74$ & $404.27^{b} \pm 0.54$ & $384.15^{c} \pm 0.41$ & $359.74^{d} \pm 0.51$ & \\
\hline
\end{tabular}

${ }^{1}$ Means in the same column with different letters are significantly different $(p \leq 0.05)$, LSD $=5.413$

${ }^{2}$ Means in the same row with different letters are significantly different $(p \leq 0.05), L S D=3.842$

Similar alkaline water retention results were reported by Saleh et al. (2019) for wheat flour pan bread substituted with different levels of pumpkin peeled, EIGammal and El kewawy (2014) for pan bread fortified with stabilized rice bran $(20-40 \%)$ and Assem (2013) for corn tortilla substituted with $10-30 \%$ millet flour. This result has differed from that reported by Abd El-Kader and Hendawy (2013) as respect to rice bran concentration and it is in good agreement as respect to storage period. The alkaline water retention capacity of tortilla prepared with corn flour at $10 \%$ RBPC was increased by $13.67 \%$ as compared with control tortilla. However, it reduced after 72 hours of storage period by $13.92 \%$.

\section{Color of tortilla}

Tortilla prepared with rice bran protein concentrate had lower $(P \leq 0.05)$ lightness $\left(L^{*}=69.58-80.13\right)$ and yellowness $\left(b^{*}=\right.$ 21.93-30.07) and higher $(P \leq 0.05)$ redness $\left(a^{*}=1.84-4.11\right)$ than control tortilla (Table 4). The dark color (lower $L^{*}$ values) of tortilla prepared with different levels of rice bran protein concentrate is attributed to the dark color of rice bran protein concentrate itself compared with corn flour. Increasing the level of rice bran protein concentrate in the tortilla resulted in significant $(P \leq 0.05)$ decrease in lightness $\left(L^{*}\right)$ and yellowness $\left(b^{*}\right)$ values of the tortilla. However, Redness $\left(a^{*}\right)$ value was increased. These results are in good agreement with $L^{*}$ and $b^{*}$ values reported by Lecuona-Villanueva et al. (2012) for the native maize tortilla fortified with protein concentrate from Phaseolus lunatus. Anil (2012) Indicated that Turkish bread supplemented with rice bran had lower $L^{*}$ values and higher $a^{*}$ and $b^{*}$ values as compared to control bread. However, these results have differed from those reported by Argüello-García et al. (2017) for fortified corn tortilla dough with nontoxic Jatropha curcas.

The total color (the difference from the control, $\Delta E)$ of tortilla (3.48-16.84) prepared with rice bran protein concentrate was increased by increasing the level of rice bran protein concentrate in the tortilla formula. These results have differed from those reported by LecuonaVillanueva et al. (2012) who reported that the $\Delta \mathrm{E}$ values of the native maize tortilla fortified with protein concentrate from Phaseolus lunatus were decreased with the of levels protein concentrate.

\section{Sensory properties of tortilla}

Non-significant $(p>0.05)$ differences in odor and taste were observed between control tortilla and tortilla prepared by replacing corn flour with rice bran protein concentrate up to $7.5 \%$ replacement level 
(Table 5). At $10 \%$ replacement level, odor and taste of tortilla had lower ( $p \leq 0.05$ ) rating scores than other tortilla samples. The texture (5.06-6.88) and overall acceptability (5.55-6.95) scores of tortilla were improved by replacing corn flour with different replacement levels of rice bran protein concentrate as compared to control (4.45 and 5.10, respectively). The highest ( $p \leq 0.05$ ) texture and overall acceptability scores were observed in tortilla prepared with $7.5 \%$ rice bran protein concentrate. The control tortilla had higher $(p \leq 0.05)$ color score than tortilla prepared with rice bran protein concentrate.

The color of the tortilla was significantly ( $p \leq 0.05)$ decreased by increasing the level of rice bran protein concentrate. These results were supported by the results reported in Table 4. Ameh et al. (2013) reported that bread supplemented with stabilized rice bran had dark crust and crumb colors. Control tortilla had rating scores ranged from 4.35 (neither like nor dislike) to $\mathbf{6 . 7 5}$ (like very much) for all sensory properties. However, tortilla prepared with $7.5 \%$ RBPC had rating scores ranged from 5.35 (like moderately) to 6.95 (like very much) for all sensory properties. Therefore, tortilla prepared with $7.5 \%$ rice bran protein concentrate was selected for evaluating essential amino acids as compared with control tortilla. Lecuona-Villanueva et al. (2012) reported that fortification of corn tortilla with protein concentrate from Phaseolus lunatus improved the nutritive value of tortilla with accepted sensory properties.

Table (4): Color of tortilla prepared by replacing yellow corn flour with different levels of rice bran protein concentrate

\begin{tabular}{lcccc}
\hline Replacer levels (\%) & $\mathrm{L}^{*}$ & $\mathrm{a}^{*}$ & $\mathrm{~b}^{*}$ & $\Delta \mathrm{E}$ \\
\hline 0 & $83.33^{\mathrm{a}} \pm 0.24$ & $0.98^{\mathrm{e}} \pm 0.01$ & $31.13^{\mathrm{a}} \pm 0.17$ & - \\
2.5 & $80.13^{\mathrm{b}} \pm 0.27$ & $1.84^{\mathrm{d}} \pm 0.09$ & $30.07^{\mathrm{b}} \pm 0.01$ & $3.48^{\mathrm{d}} \pm 0.24$ \\
5 & $78.79^{\mathrm{c}} \pm 0.09$ & $2.18^{\mathrm{c}} \pm 0.05$ & $29.47^{\mathrm{c}} \pm 0.11$ & $4.98^{\mathrm{c}} \pm 0.17$ \\
7.5 & $72.32^{\mathrm{d}} \pm 0.25$ & $2.52^{\mathrm{b}} \pm 0.01$ & $23.37^{\mathrm{d}} \pm 0.10$ & $13.56^{\mathrm{b}} \pm 0.21$ \\
10 & $69.58^{\mathrm{e}} \pm 0.18$ & $4.11^{\mathrm{a}} \pm 0.01$ & $21.93^{\mathrm{e}} \pm 0.01$ & $16.84^{\mathrm{a}} \pm 0.18$ \\
LSD & 1.16 & 0.12 & 0.21 & 0.34 \\
\hline
\end{tabular}

Means in the same column with different letters are significantly different $(p \leq 0.05)$

Table (5): Sensory properties of tortilla prepared by replacing corn flour with different levels of rice bran protein concentrate

\begin{tabular}{|c|c|c|c|c|c|}
\hline $\begin{array}{l}\text { Replacer } \\
\text { levels (\%) }\end{array}$ & Color & Odor & Taste & Texture & $\begin{array}{c}\text { Overall } \\
\text { acceptability }\end{array}$ \\
\hline 0 & $6.65^{a} \pm 0.24$ & $6.75^{a} \pm 0.26$ & $6.49^{a} \pm 0.31$ & $4.35^{e} \pm 0.24$ & $5.10^{e} \pm 0.55$ \\
\hline 2.5 & $6.15^{b} \pm 0.24$ & $6.65^{a} \pm 0.36$ & $6.33^{a} \pm 0.32$ & $5.06^{d} \pm 0.33$ & $6.10^{c} \pm 0.41$ \\
\hline 5 & $5.90^{\mathrm{c}} \pm 0.43$ & $6.54^{a} \pm 0.27$ & $6.23^{a} \pm 0.40$ & $5.81^{c} \pm 0.21$ & $6.45^{b} \pm 0.15$ \\
\hline 7.5 & $5.35^{d} \pm 0.33$ & $6.48^{a} \pm 0.22$ & $6.26^{a} \pm 0.42$ & $6.88^{a} \pm 0.11$ & $6.95^{\mathrm{a}} \pm 0.05$ \\
\hline 10 & $4.65^{\mathrm{e}} \pm 1.47$ & $5.35^{b} \pm 0.41$ & $5.30^{b} \pm 0.34$ & $6.30^{b} \pm 0.25$ & $5.55^{d} \pm 0.34$ \\
\hline LSD & 0.21 & 0.29 & 0.33 & 0.22 & 0.32 \\
\hline
\end{tabular}


Amino acid profile of tortilla

Essential amino acid compositions of tortilla prepared by replacing corn flour with $7.5 \%$ of rice bran protein concentrate as compared with control tortilla and FAO/WHO/UNU (1985) amino acid pattern were presented in Table (6). Leucine and aromatic amino acids were the major essential amino acids in control tortilla and tortilla prepared by replacing corn flour with $7.5 \%$ of rice bran protein concentrate. However, the lowest amino acids were lysine and tryptophan in control tortilla and lysine in a tortilla with $7.5 \%$ rice bran protein concentrate. Tortilla prepared with $7.5 \%$ rice bran protein concentrate had higher lysine $(27.31 \%)$ and tryptophan (33.33\%) than control tortilla. The increase in lysine and tryptophan is attributed to rice bran protein concentrate content in a tortilla which had higher lysine and tryptophan contents than those in corn flour. Acevedo-Pacheco and SernaSaldı'var (2016) reported that fortification of maize tortilla with $6 \%$ defatted soybean flour improved the lysine and tryptophan contents. Lecuona-Villanueva et al. (2012) reported that fortification of corn tortilla with protein concentrate from Phaseolus lunatus resulted in an increase in available lysine and tryptophan.

On the basis of FAO/WHO/UNU (1985) requirements, control tortilla and tortilla prepared with $7.5 \%$ of rice bran protein concentrate had higher total and individual essential amino acids than the standard pattern for the adults. Also, control tortilla and tortilla prepared with $7.5 \%$ of rice bran protein concentrate had higher total and individual essential amino acids than the standard pattern for the child (10-12 years) except for lysine and tryptophan for control tortilla and lysine for tortilla prepared with $7.5 \%$ rice bran protein concentrate. The standard pattern for the child (10-12 years) had higher Lysine $(\mathbf{4 0 . 9 1 \% )}$ and tryptophan $(25 \%)$ than control tortilla and higher lysine $(24.77 \%)$ than tortilla prepared with $7.5 \%$ rice bran protein concentrate.

Table (6): Essential amino acids of control tortilla and tortilla prepared by replacing corn flour with $7.5 \%$ of rice bran protein concentrate as compared with FAO/WHO/UNU (1985) amino acid pattern

\begin{tabular}{lcccc}
\hline Amino acids (g/100g) & \multicolumn{2}{c}{ Tortilla } & \multicolumn{2}{c}{ FAO/WHO/UNU (1985) } \\
\cline { 2 - 5 } & control & $\begin{array}{c}{ }^{1} \text { RBPC } \\
7.5 \%\end{array}$ & $\begin{array}{c}\text { Child 10-12 } \\
\text { years }\end{array}$ & Adult \\
\hline Isoleucine & 3.09 & 3.31 & 2.8 & 1.3 \\
Leucine & 9.04 & 8.02 & 4.4 & 1.9 \\
Lysine & 2.60 & 3.31 & 4.4 & 1.6 \\
Aromatic amino acids & 7.75 & 7.35 & 2.2 & 1.9 \\
Therionine & 3.09 & 3.38 & 2.8 & 0.9 \\
Valine & 4.33 & 4.63 & 2.5 & 1.3 \\
Histidine & 2.48 & 2.50 & 1.9 & 1.6 \\
Sulfur amino acids & 4.83 & 4.04 & 2.2 & 1.7 \\
Tryptophan & 0.69 & 0.92 & 0.9 & 0.5 \\
Total essential amino acid & 37.9 & 37.46 & 24.1 & 12.7 \\
\hline
\end{tabular}




\section{CONCLUSION}

It could be concluded that replacing corn flour with $7.5 \%$ rice bran protein concentrate resulted in an improvement of nutritive value without negative effects on its sensory properties.

\section{REFERENCES}

Abd El-Kader, M. H. and Y. T. Hendawy (2013). Heat stabilization of rice bran and its application in some bakery products. Egypt. J. Agric. Res, 91: 6784.

Acevedo-Pacheco, L. and S. O. SernaSaldívar (2016). In vivo protein quality of selected cereal-based staple foods enriched with soybean proteins. Food Nutr. Res. 60:31382, https://doi.org/10.3402/fnr.v60.31382

Agama, A. E., V. R. Rendón, J. Tovar, L. O. Paredes, H. J. J. Islas and P. L. A. Bello (2004). In vitro starch digestibility changes during storage of maize flour tortillas. Nahrung/Food, 48:38-42.

Aksson, W. R. and M. A. Stammann (1983). A pepsin pancreatin digest index of protein quality evaluation. $\mathbf{J}$. Nut., 64:257-261.

Alviola, J. N., R. D. Waniska and L. W. Rooney (2008). Role of Gluten in Flour Tortilla Staling. Cereal Chem. 85:295300.

Ameh, M. O., D. I. Gernah and B. D. Igbabul (2013). Physico-chemical and sensory evaluation of wheat bread supplemented with stabilized undefatted rice bran. Food nutr. Sci. 4:43-48.

Anil, M. (2012). Effect of wheat bran, corn bran, rice bran and oat bran supplementation on the properties of pide. J. Food Proc. and Preserv. 36:276-283.

AOAC (2010). Official Methods of Analysis of Association of Official
Analytical Chemists. 18th Edition, Washington, DC, USA.

Argüello-García, E., J. Martínez- Herrera, L. Córdova-Téllez, $0 . \quad$ SánchezSánchez and T. Corona-Torres (2017). Textural, chemical and sensorial properties of maize tortillas fortified with nontoxic Jatropha curcas L. flour. CyTA - J. Food, 15:301-306.

Assem, N. H. A. (2013). Effect of Supplementation with Millet Flour on Tortilla Quality. J. Life Sci. and Tech., 1: 62-64.

Chandi, G. K. and D. S. Sogi (2007). Biochemical characterization of rice protein fractions. Inter. J. Food Sci. Tech., 42:1357-1362.

El-Gammal, R. E. and H.E. El kewawy (2014). Effect of addition of stabilized rice bran on physical, rheological and chemical charatarestics of pan bread. J. Food and Dairy Sci., Mansoura Univ., 5: 813-825.

FAO/WHO/UNU (1985). Energy and Protein Requirements. Report of a Joint FAO/WHO/UNU meeting Series No.724, WHO, Geneva, Switzerland.

Hernandes, H. H. and L. S. Bates (1969). A simple method for tryptophan determination in maize. CYMMIT Research Bulletin 13: 134-139.

Kim, S. K. and B. L. D'Appolonia (1977). Bread staling studies. I. Effect of protein content on staling rate and bread crumb content on staling rate and bread crumb pasting properties. Cereal Chemistry, 54:207215

Kitterman, J. S. and G. L. Rubenthalor (1971). Assessing the quality of early generation wheat selection with micro AWRC test. Cereal Sci. Today, 16:313316.

Lecuona-Villanueva, A., D. A. BetancurAncona, L. A. Chel-Guerrero and A. F. Castellanos-Ruelas (2012). Protein Fortification of Corn Tortillas: Effects 
on Physicochemical Characteristics, Nutritional Value and Acceptance. Food Nutr. Scie., 3:1658-1663.

Montemayor-Mora, G., K. E. Herna'ndezReyes, E. Heredia-Olea, E. Pe'rezCarrillo, A. A. Chew-Guevara and S. O. Serna-Saldı'var (2018). Rheology, acceptability and texture of wheat flour tortillas supplemented with soybean residue. J. Food Sci. Tech.

Michael, O. Ameh, Dick I. Gernah and Bibiana D. Igbabul (2013). PhysicoChemical and Sensory Evaluation of Wheat Bread Supplemented with Stabilized Undefatted Rice Bran. Food and Nutrition Sciences, 4: 43-48.

Pascut, S., N. Kelekci and R. D. Waniska (2004). Effects of wheat protein fractions on flour tortilla quality. Cereal Chem. 81: 38-43.

Rendón-Villalobos, R., E. AgamaAcevedo, P. OsorioDíaz, J. Tovar and L.A. Bello-Pérez (2009). Proximal composition and in vitro starch digestibility in flaxseed added corn tortilla. J. Sci. Food and Agri., 89: 537541.

Rendon-Villalobos, R., A. Ortiz-Sanchez, J. Solorza-Feria and C. A. TrujilloHernandez (2012). Formulation, physicochemical, nutritional and sensorial evaluation of corn tortillas supplemented with chía seed (Salvia hispanica L.). Czech J. Food Sci., 30:118-125.

Rohrer, C. A. and T. J. Siebenmorgen (2004). Nutraceutical Concentrations within the bran of various rice kernel thickness fractions. J. Biosystems Engineering, 88: 453-460.

Saleh, E. H., E. H. Mansour and H. E. Youssef (2019). Utilization of pumpkin fractions in the preparation of pan bread as a functional food. 6th Annual International Scientific Conference, Specific studies and their role in activating tourism for the development of the national economy, Tanta University, Faculty of Specific Education, March 6-9, Hurghada, Egypt.

Salinas, M. Y., L. E. B. Castillo, C. M. G. Vázquez and G. M. O. Buendía (2011). Blends of waxy with normal maize and their effect on tortilla quality. Revista Mexicana Ciencia Agrícola, 2: 689-702.

Serna-Saldivar, S. O., L. W. Rooney and R. D. Waniska (1988). Wheat flour tortilla production. Cereal Foods World 33: 855-863.

Sohail, M., A. Rakha, M. S. Butt, M. J. Iqbal and S. Rashid (2017). Rice bran nutraceutics: A comprehensive review. Crit. Rev. Food Sci. Nutr., 57: 3771-3780.

Wang, M., N. S. Hettiarachchy, M. Qi, W. Burks and T. Siebenmorgen (1999). Preparation and functional properties of rice bran protein isolate. J. Agri. and Food Chem., 47: 411-416.

Waniska, R. D., M. Cepeda, B. Sullins King, J. L. Adams, L. W. Rooney, P. I. Torres, G. L. Lookhart, S. R. Beans, J. D. Wilson and D. B. Betchel (2004). Effects of flour properties on tortilla qualities. Cereal Foods World 49: 237 244. 
خصائص جودة تورتيلا الذرة المعدة مع نسب مختلفة من بروتين نخالة الأرز المركز

أحمد محمد عز الدين على")، عصام الاين حافظ منصور (†)، منى عبد المنعم محمد على(")،

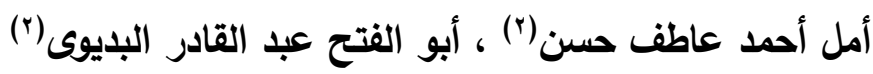

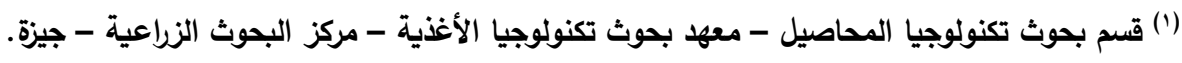

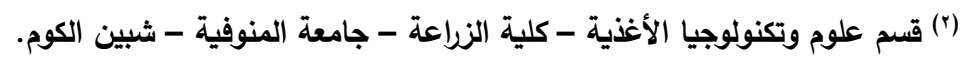

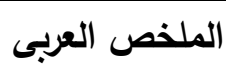

أجريت هذه الدراسة لتقييم إمكانية الاستبدال الجزئي لاقيق الذرة الصفراء مع بروتين نخالة الأرز المركز (RBPC)

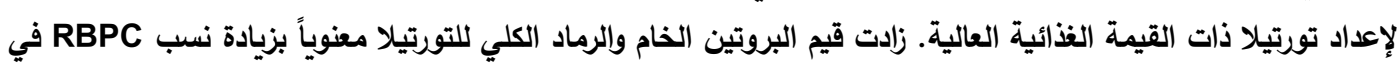

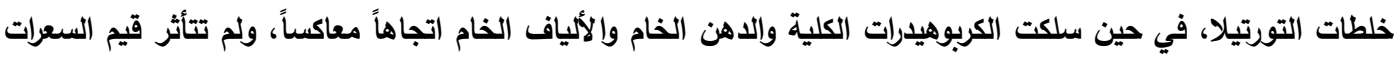

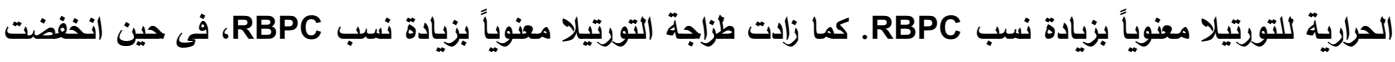

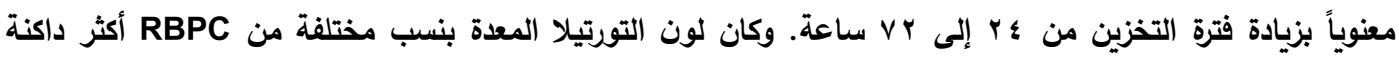

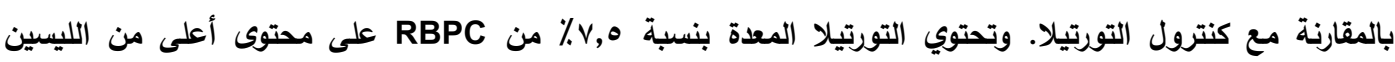

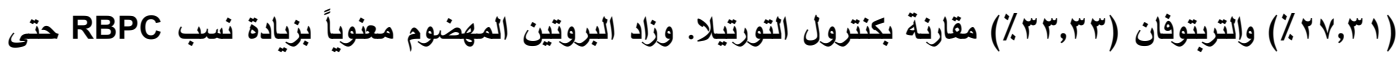

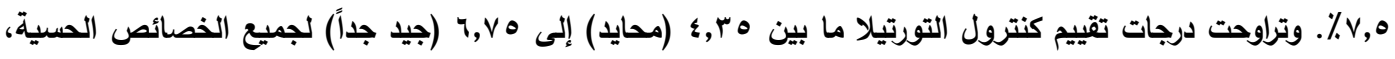

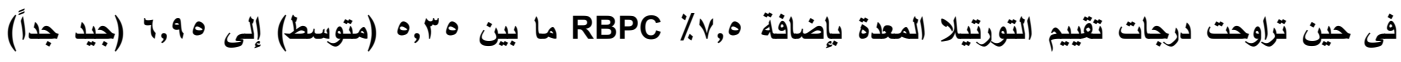

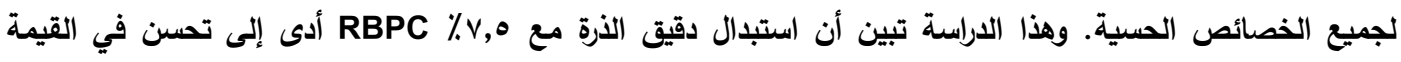
الغذائية ودرجة القبول العام للتورتيلا. الكلمات الادالة: دقيق الذرة، بروتين نخالة الأزز المركز، تورتيلا، الليسين، القبول العام

السادة المحكمين أ.د/ سعد ميخائيل يوسف موسى مركز البحوث الزراعية - الجيزة

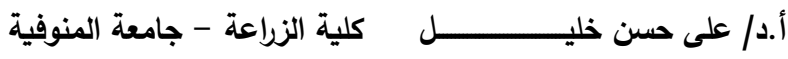


A. M. Ezzeldeen, et al., 